\title{
The Ophuirid and the Sea Star IgKappa Genes
}

\section{Michel Leclerc*}

556 rue Isabelle Romée, Immunology of Invertebrates, France

*Corresponding Author: 556 rue Isabelle Romée, Immunology of Invertebrates, France
Received: September 09, 2020

Published: March 22, 2021

(C) All rights are reserved by Michel Leclerc.

\begin{abstract}
This study was performed from an evolutive point of view. The sea star and ophuirid IgKappa genes for so extended a period of evolution in organisms as distinctively different as sea star, fish, mammal, indicate that they play an essential role in the survival of organisms: role in the regulation of immune response, in Asterids and Ophuirids. The presence of Fc receptor gene, Fab gene in Asterias rubens complete these data.
\end{abstract}

Keywords: Ophuirid; Sea Star; IgKappa Genes

\section{Introduction}

The purpose of this work is to draw attention to the mass of Igkappa genes that has accumulated on the sea star immune system since 2011, on the ophuirid immune system since 2018. From these years, genomes of immunized and non-immunized animals to HRP (horse-radish peroxidase) have been studied [1,2]. Although sea star IgKappa gene has been isolated [2] and found in mouse, this gene has also been detected in fish (Zebra fish and Larimichthys crocea) and mammals.

\section{Results}

The sea star Igkappa gene is clearly the oldest IgKappa gene of the immune system of animals.

So, the ophuirid Igkappa gene. They show already two Ig sites [2] or more. The forms of Igkappa genes are all found in vertebrates.

The preservation of the Igkappa gene in immunized and nonimmunized sea stars is an excellent opportunity for further experiments. It is important to notice that the Igkappa chain V-III region HAH of Tupaia chinensis is situated (in the assumptions behind the theory of evolution) between the Igkappa chain precursor V-II region (RPMI/133) and Igkappa chain precursor V-IV region/121.

\section{Conclusion}

The preservation of the IgKappa genes for so extended a period of evolution in organisms as distinctively different as sea star, ophuirid, fish, rodent, mammal, indicates that they play an essential role in the survival of the organisms, role in the regulation of the immune response.
Additionally, the existence of members of the IgKappa gene family with conserved functional characters, indicate that the sea star and ophuirid IgKappa gene have evolved prior to the evolutionary divergence between invertebrate and vertebrates.

On the other hand, the discovery of a Fc receptor gene, of a Fab gene, of MHC class I and class II genes in Echinodermata genomes, crroborate the presence of the primitive Invertebrate antibody: The Well-known IPA.

\section{Bibliography}

1. Leclerc M., et al. "Evidence of Kappa genes in the sea-star Asterias rubens (Echinoderma)". Immunology Letters 138.19 (2011): 197-198.

2. Vincent N., et al. "A new gene in A. rubens: A sea star Ig kappa gene". Metagene 2 (2014): 320-322.

\section{Assets from publication with us}

- Prompt Acknowledgement after receiving the article

- Thorough Double blinded peer review

- Rapid Publication

- Issue of Publication Certificate

- High visibility of your Published work

Website: https://www.actascientific.com/

Submit Article: https://www.actascientific.com/submission.php Email us: editor@actascientific.com

Contact us: +919182824667 